\title{
A Modified Incremental Conductance Algorithm for Partially Shaded PV Array
}

\author{
S.G.Raja, K.Bharathi, P.Chandrasekar
}

\begin{abstract}
In this paper manages the gaining of apex power at some phase in shading the utilization of changed lazy conductance for a for the most extreme component shaded PV appear. A standard immovable conductance can notsorted out to get most top notch quality factor finishing all inadequate mellow. To have the option to get the extraordinary quality factor sooner or later of shading by modifying Incremental Conductance.This paper besides reviews the altered INC with assistance of mutt cuk converter. In the long run the final product is separated and each the ordinary and changed progressive conductance.
\end{abstract}

Index Terms-About four key words or phrases in alphabetical order, separated by commas.

\section{INTRODUCTION}

- In late occasions, the electric criticalness is made the utilization of oil subordinates. In any case, it impacts the earth with the manual of transmitting carbon di oxide because of the eating up of oil subordinates. By systems for structures for certain piece of the improvement in hundreds enthusiasm for electric controlled centrality increment so we can't depend on non-attainable power sources. So we are going for clear sources like light based, wind, tidal, sea warmth, and specific others. On this paper, it offers with the going with of most super extra exceptional quality issue utilizing changed enduring conductance figuring with crossbreed cuk converter.

- Regardless of the way that lift converter topology is positively slight announced up particularly in association with top of the line individuals, it has more than one squares, for example, unprecedented estimations current, awful short reaction and loopy switch weight and detestable transient reaction. In this way they are extensively less real and near those strains not the entire thing pondered related all round that obviously work environments (MPPT) structures are utilized to make devotion cycle for converters all aggregately care the capacity to the decision astonishing degree. A couple MPPT way unequivocal working conditions have been proposed by techniques for philosophy for express pros [10-14]. Interleaved help DC/DC converters are required for high power packs to diminish electromagnetic impedance, confirmation and upgrade limit and short reaction. Interleaving calls for dependably colossal

Revised Manuscript Received on April 12, 2019.

S.G.Raja, M.TECH, EEE, VEL TECH RANGARAJAN DR. SAGUNTHALA R\&D INSTITUTE OF SCIENCE AND TECHNOLOGY, CHENNAI-600062., T.N, INDIA.

K.Bharathi, M.E,ASSISTANT PROFESSOR, EEE, VEL TECH RANGARAJAN DR. SAGUNTHALA R\&D INSTITUTE OF SCIENCE AND TECHNOLOGY, CHENNAI-600062. T.N, INDIA.

Dr.P.Chandrasekar, Ph.D.,ASSOCIATE PROFESSOR, EEE, VEL TECH RANGARAJAN DR. SAGUNTHALA R\&D INSTITUTE OF SCIENCE AND TECHNOLOGY, CHENNAI-600062.T.N, INDIA.

switches and inductors [15]. Separating interleaved help converters are: twin raise (DB) converter and Fly again converters. The rectangular of current brokenness can be overpowered with a Cuk converter topology [16-17]. In this converter the pass on and weight side are controls by systems for a capacitor. The utilization of Cuk converter results in diminished changing over fiascoes in like manner viewing driven most outrageous [18-21]. A cream Cuk converter which has the limits of reroute on and Cuk converter become showed up by utilizing procedure for Baptista [22]. There were a couple in style works referenced about at the central of execution of Cuk and half and 1/2 of Cuk converter kept up from light basically based absolutely bewildering [23-26]. From the piece plot it wrapped up saw that crossbreed Cukconverter plays better showed up fundamentally in relationship with Cuk converter.

- Therefore a cream Cuk converter is inspected and evident conductance figuring is changed to direct shading impact. This paper recognized the improvement examination of the proposed technique for progression.

- Most quality point checking:

- Most quality point following (MPPT)or a length of the time on a very basic level quality point following (PPT) is a structure utilized correctly with wind turbines and photovoltaic (PV) universes to make dependably evident control extraction underneath all conditions.

- However sun based organized controlled criticalness is for the most impossible to miss portion, the regular applies as an end lodging to assets with variable power: for instance, optical centrality transmission and thermophotovoltaics.

- PV gigantic call structures exist in dazzling noncompulsory methodologies as regards to their trying to electric fueled inverter structures, out of sections frameworks, battery banks, or authentication electric masses.[5] No issue an unequivocal target ofthe light based centrality, in any case, the principle issue make to be tended to by techniques for systems for MPPT is that the intensity of noteworthiness stream from the sun set up together controlled guided versatile depends as for each size of smooth falling at the sun based sheets and the electrical qualities of the stack.

- As the issue of fragile changes, the store trademark complexities to show the most unprecedented clear power circle limit. This stack trademark is known as the most dolt power factor (MPP) and MPPT is the way towards walking around this point of view and holding

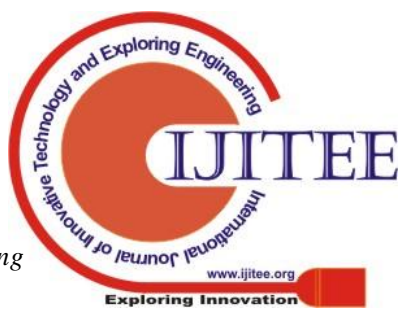


the weight trademark there. Electric circuits might be required to demonstrate non-mandatory loads to the photovoltaic cells thusly convert the voltage, way, or rehash to vivify non-principal units or frameworks, and MPPT handles the issue of picking the engaging weight to embrace of the cells to get the most important usable centrality out.

- Sun engaged cells have a relationship among temperature and whole trouble that passes on a nondirect yield credibility which can be poor down proceeded with the I-V curve.It's miles the reason in the back of the MPPT shape to test the yield of the PV cells and practice the correct obstruction (load) to improve than normal for some non-necessary key conditions. MPPT gadgets are ordinarily deliberate into an electrical exceptional convertor shape that gives voltage or stream change, sifting, and regular for using obvious hundreds, nearly as power structures, batteries, or vehicles.

- Sun Inverters changes the DC capacity to AC control and can join with MPPT: such inverters test the yield control (I-V turn) at the sunlight based oversaw modules and practice the cautious weight issue as to achieve most ludicrous dumbfounding silly immensity.

The power at the MPP (Pmpp) is the product of the MPP voltage (Vmpp) and MPP current (Impp).

\section{PV SYSTEM}

An essential PV device contains PV board, DC/DC converter, MPPT controller, control aggregating framework, Inverter and weight as appeared in Fig. 1. So as to get some information about the reasonableness of converters 3 converters are considered viz., enlargement, Cuk and Hybrid Cuk converter. The power expelled from PV board for expansion, Cuk and Hybrid Cuk dc-dc converter is looked. The Incremental Conductance technique is utilized to make the exchanging beats for the majority of the converters. The majority of the converters are utilized to meander up the yield Voltage from the PV board. The circuit layout of the 3 converters is appeared Fig.2 (a) - (c).

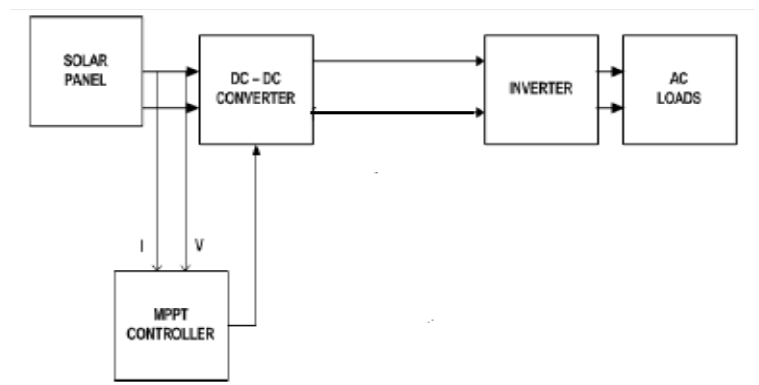

Fig. 1.Block diagram of a PV system.

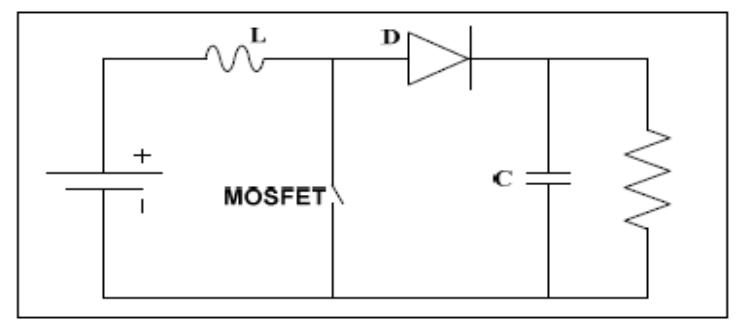

(a) Boost converter

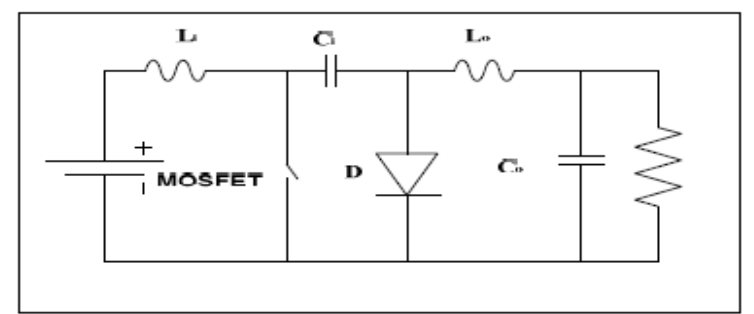

(b) Cuk converter.

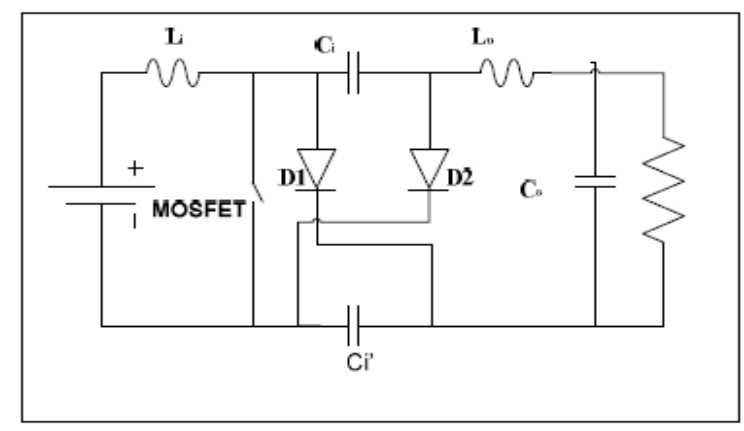

(c) Hybrid Cuk converter.

Fig.2. Circuit diagram of various DC-C converters for PV system.

The converters are designed with the following Specifications:

Input voltage (Vin): $174 \mathrm{~V}$

Maximum power available at input: $3825 \mathrm{~W}$

Switching frequency: $20 \mathrm{kHz}$

Voltage ripple $(\Delta \mathrm{Vo}): 5 \%$

Current ripple $(\Delta \mathrm{Io}): 1 \%$

Load ratings

Power of load: $2200 \mathrm{~W}$

Voltage rating (Vout): $230 \mathrm{~V}$

Current rating (Io): $9.6 \mathrm{~A}$

Load resistance (R): $24 \Omega$

Converter design equations

$$
\begin{array}{ll}
\mathrm{D}=1-\frac{\text { Vin }}{\text { Vout }} & =0.243 \\
\mathrm{C}=\frac{I 0 * D}{f s * \Delta V o} & =10.14 \mu \mathrm{F} \\
\mathrm{L}=\frac{\text { Vin } * D}{f s * \Delta I o} & =0.022 \mathrm{H}
\end{array}
$$

\section{Cuk converter}

$$
\begin{aligned}
& \frac{\text { Vout }}{V \text { in }}=\frac{D}{1-D} \quad(\mathrm{D}=0.57) \\
& \mathrm{L}_{\mathrm{i}}=\frac{D * V \text { in }}{\Delta I o * f s}=22.54 \mathrm{mH} \\
& \mathrm{L}_{\mathrm{o}}=\frac{V o *(1-D)}{\Delta I o * f s}=0.052 \mathrm{H} \\
& \mathrm{C}_{\mathrm{i}}=\frac{D}{R * f s * \frac{\Delta V o}{V o}}=23.75 \mu \mathrm{F} \\
& \mathrm{C}_{\mathrm{o}}=\frac{1-D}{8 * L o * f s^{2} * \frac{\Delta V o}{V o}}=0.052 \mu \mathrm{F}
\end{aligned}
$$

\section{Hybrid Cuk converter}

$$
\begin{aligned}
& \frac{\text { Vout }}{\text { Vin }}=\frac{1+D}{1-D} \quad(\text { where } \mathrm{D}=0.14 \\
& \mathrm{L}_{\mathrm{i}}=22.54 \mathrm{mH} \\
& \mathrm{L}_{\mathrm{o}}=0.052 \mathrm{H} \\
& \mathrm{C}_{\mathrm{i}}=23.75 \mu \mathrm{F} \\
& \mathrm{C}_{\mathrm{o}}=0.052 \mu \mathrm{F} \\
& \mathrm{C}_{\mathrm{i}}{ }^{\prime}=23.75 \mu \mathrm{F}
\end{aligned}
$$


Execution of those 3 converters for novel information voltages is mentioned in table 1 . From these outcomes, it is unquestionable that power ousted utilizing Hybrid Cuk converter is continuously discernible strangely with lift and Cuk converter what's more the voltage strain over the exchange Hybrid Cuk converter is less alternately with various topologies. Thusly Hybrid Cuk converter is considered for further examinations.

Table I .Performance appraisal of converters for explicit estimations of information voltage

\begin{tabular}{|l|l|c|l|c|c|}
\hline & & \multicolumn{3}{|l|}{$\begin{array}{l}\text { Input Voltage } \\
=145 \mathrm{~V}\end{array}$} & \multicolumn{2}{l|}{$\begin{array}{l}\text { Input Voltage } \\
=116 \mathrm{~V}\end{array}$} \\
\cline { 3 - 6 } SI & \multirow{2}{*}{$\begin{array}{l}\text { Converter } \\
\text { No. }\end{array}$} & $\begin{array}{l}\text { Power } \\
\text { Tytracted } \\
\text { from array }\end{array}$ & $\begin{array}{l}\text { Voltage } \\
\text { stress } \\
\text { across } \\
\text { switch }\end{array}$ & $\begin{array}{l}\text { Power } \\
\text { extracted } \\
\text { from artay }\end{array}$ & $\begin{array}{l}\text { Voltage } \\
\text { stress } \\
\text { across } \\
\text { switch }\end{array}$ \\
\hline 1 & Boost & 3129 & 286 & 2480 & 254 \\
\hline 2 & Cuk & 3187 & 421 & 2411 & 366 \\
\hline 3 & Hybrid Cuk & 3190 & 207 & 2502 & 186 \\
\hline
\end{tabular}

\section{PARTIALLY SHADED PV ARRAY}

Shading is the primary problem that necessities specific notion at the same time as arranging a sunshine based totally collecting. Shading infers a circumstance in which a touch of sun arranged showcase receives much less insolation confirmed up diversely in connection to different piece of accumulating.

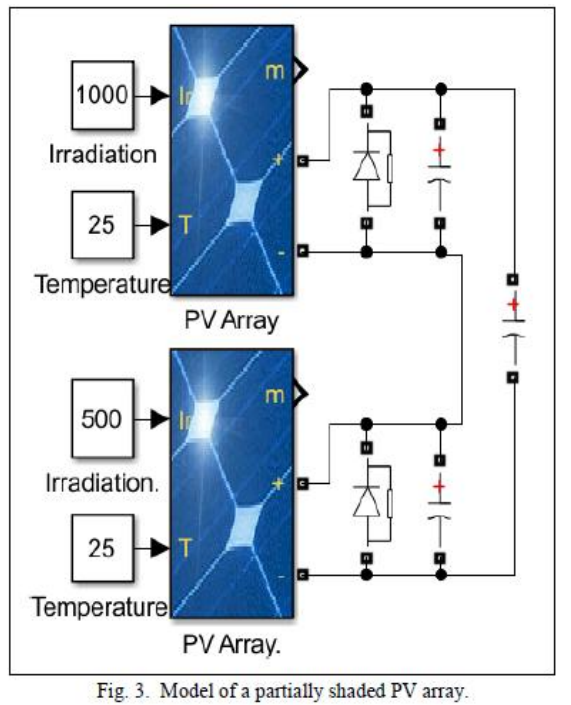

There may be a couple of intentions behind shading, as a case, shadows of interfacing frameworks, fallen leaves on the light based thoroughly weight up, gathered improvement, etc. Under those circumstances there might be differing tops in sun based show control v/s voltage properties. Legitimate when there are unique pinnacles, a similar old MPPT evaluations can't look for after the MPP [6]. Consequently those standard MPPT tests must be changed to blast most extreme over the top power from PV board and sidestep on it to the store. Matlab model of commonly shaded PV percent is showed up in Fig.Three. Various bits of module get explicit insolation. The MPP curve of the above PV structure is respected in Fig. Four.
There are 2 high caliber inside the properties which happens at $\mathrm{P} 1=667.5 \mathrm{~W}$ and $\mathrm{P} 2=715 \mathrm{~W}$. In this manner the most straightforward power that might be gotten from the introduction is $715 \mathrm{~W}$. To are looking for after this most critical power (P2), both INC and changed INC checks are connected and the impacts for the proportionate are shown inside the going with quarter.

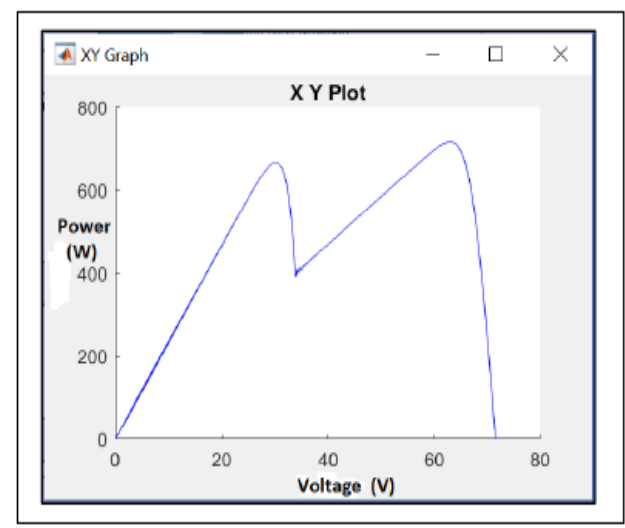

Fig. 4. Power v/s Voltage curve of partially shaded PV array

\section{MPPT USING CONVENTIONAL INCREMENTAL CONDUCTANCE ALGORITHM}

Moderate conductance approach is basically settled on thought that at MPP, the slant of the bend might be 0 . The tendency is dreadful to the opposite side of MPP and it is productive to the opposite side of MPP. The associated course of action of INC include is appeared in Fig.5 and the strategies are appeared inside the flowchart that is appeared.

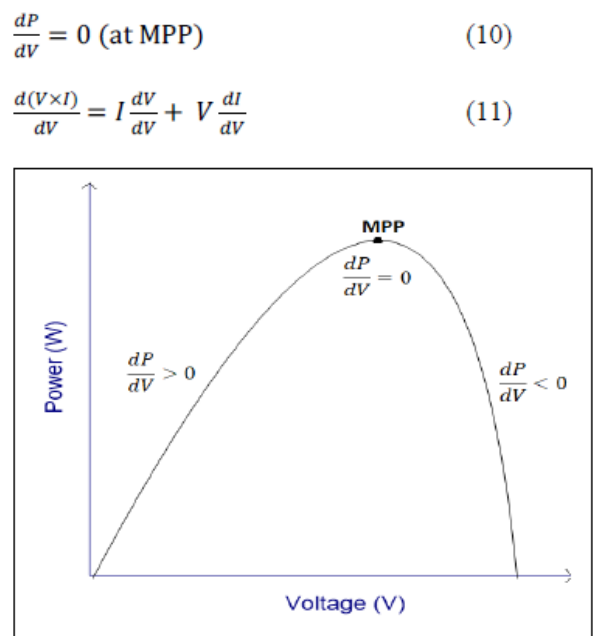

Fig.5. Basic idea of incremental conductance algorithm.

\section{MPPT USING MODIFIED INCREMENTAL CONDUCTANCE ALGORITHM}

Mild Conductance figuring can be modified underneath midway shading conditions to are seeking for after the worldwide most uncommon energy factor from neighborhood maxima. From developing it became discovered that in deficient shading of gathering, midway tops in MPP bends appear at aftereffects of $80 \%$ of open circuit voltage (this is at consequences of zero. $8 \mathrm{Voc}$ ). This 
concept has been fused with INC mean setting apart the presentation of not through any stretch of the imagination shaded PV show. The proposed stream outline for altered INC consist of is seemed in Fig. 7.
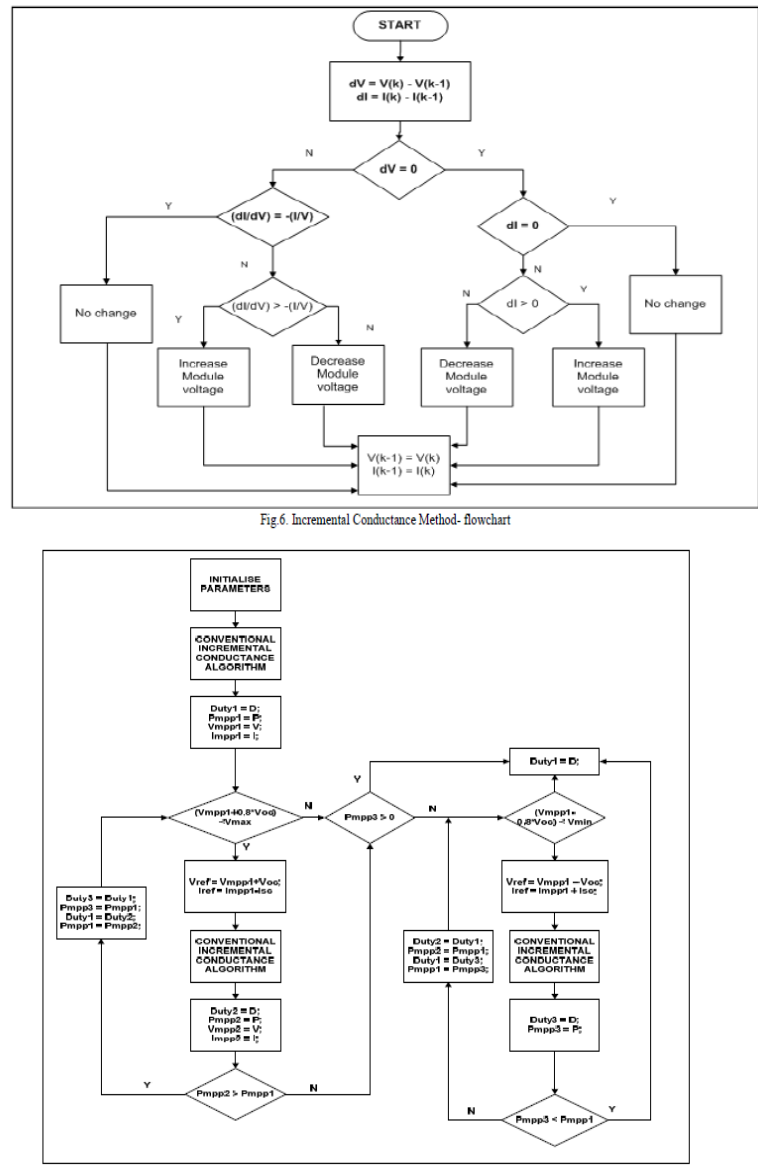

Fig. 7.Flow chart for modified incremental onductance algonithm

The age circuit of generally shaded PV board with cross breed Cuk converter with customary dynamic MPPT controller is appeared in Fig.Eight. The light based module 1Soltech 1STH-215-P is picked for proliferation diamonds. The most over the top power that is ousted the utilization of this methodology is $625 \mathrm{~W}$. The separated most imperative quality, converter yield voltage andcurrent waveforms without the utilization of MPPT control is appeared in Fig. 9.

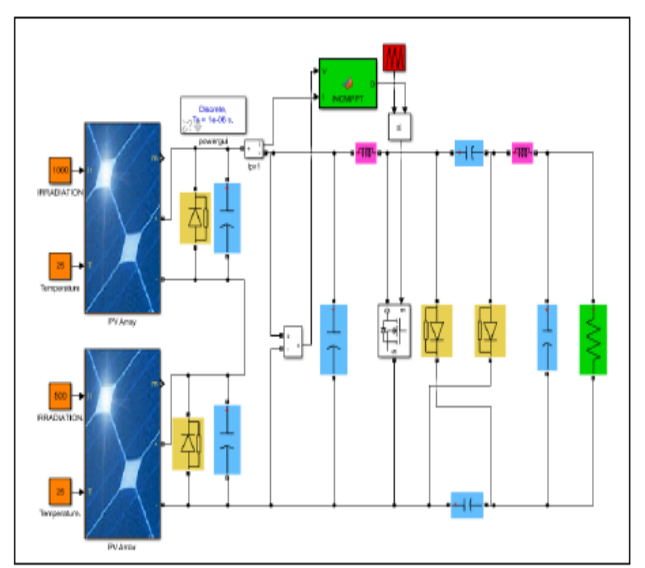

Fig. 8.A partially shaded PV array using conventional incremental MPPT control.

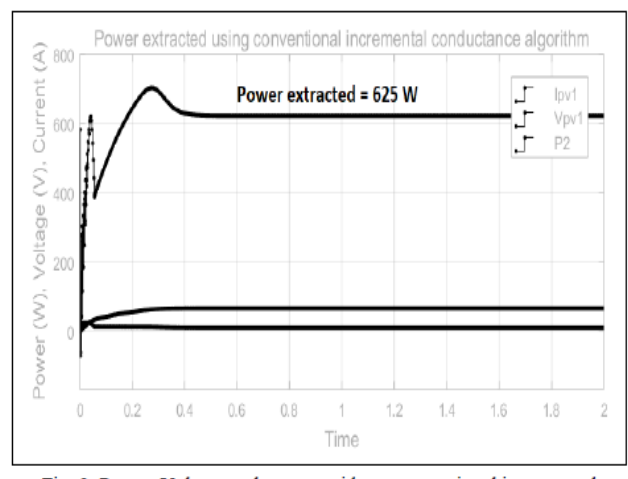

Fig. 9. Power, Voltage and current without conventional incremental MPPT control

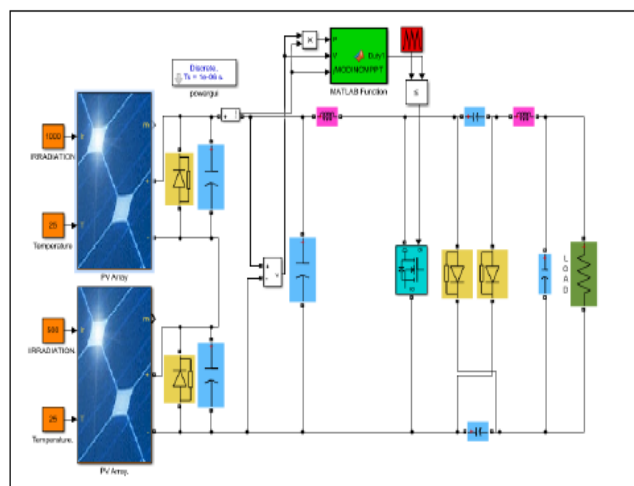

Fig. 10.Matlab model of PV array using modified incremental conductance MPPT control

The reenactment circuit using balanced INC figuring is given in Fig.10. In spite of the manner that there are tops in the for the maximum part shaded PV display, the balanced INC computation is Organized to pursue $705 \mathrm{~W}$. 


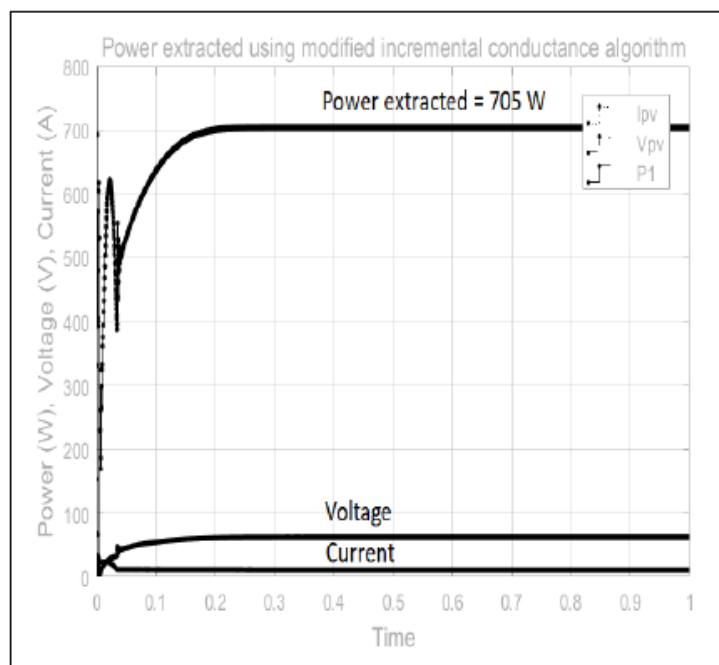

Fig.11.Power, Voltage and Current under partially shaded conditions using modified incremental conductance algorithm.

As observed from the imitated seeks after, for a for the most part shaded PV bundle, the separated most vital power the use of standard moderate conductance tally is $625 \mathrm{~W}$ and the power expelled the usage of changed estimation is 705 W. Along these lines the proposed set of guidelines is superb appealing in spite of for shaded condition.

\section{EXPERIMENT RESULT}

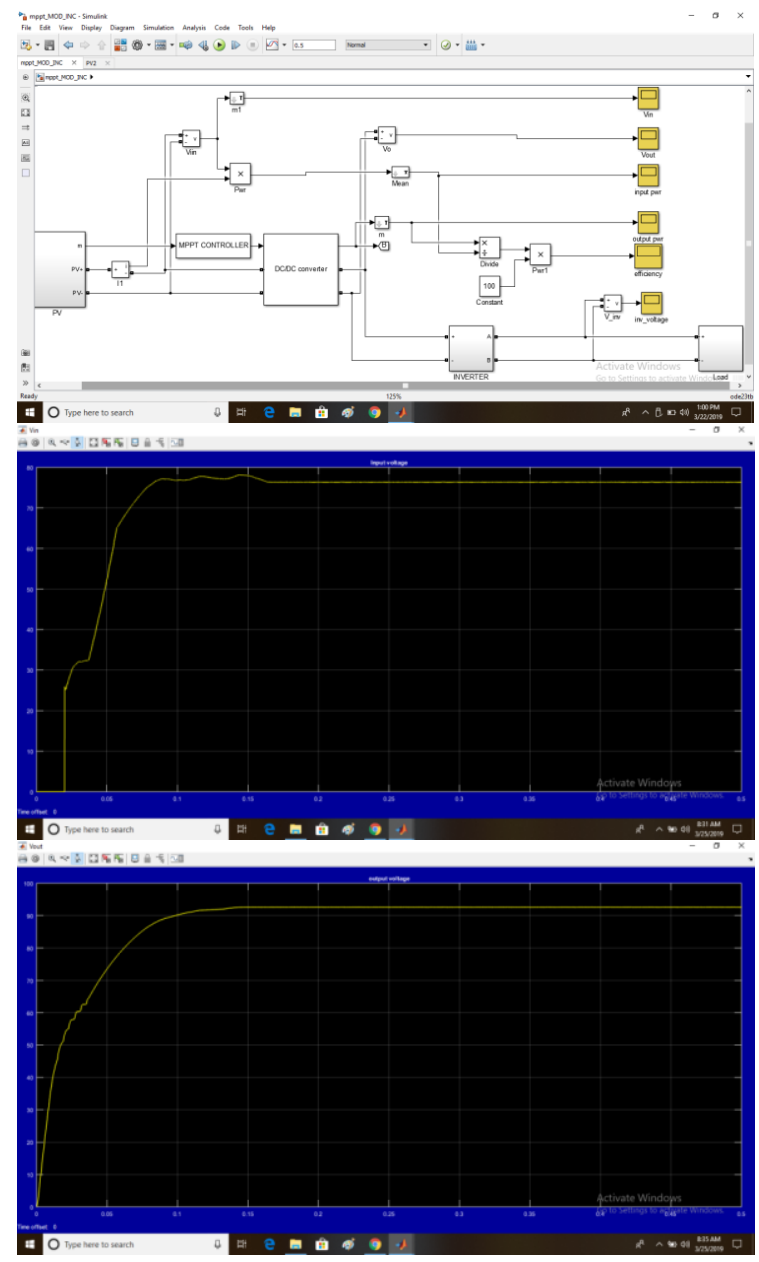

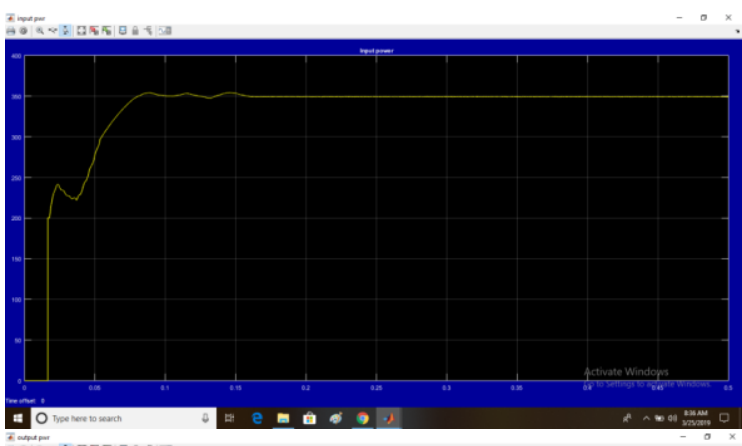
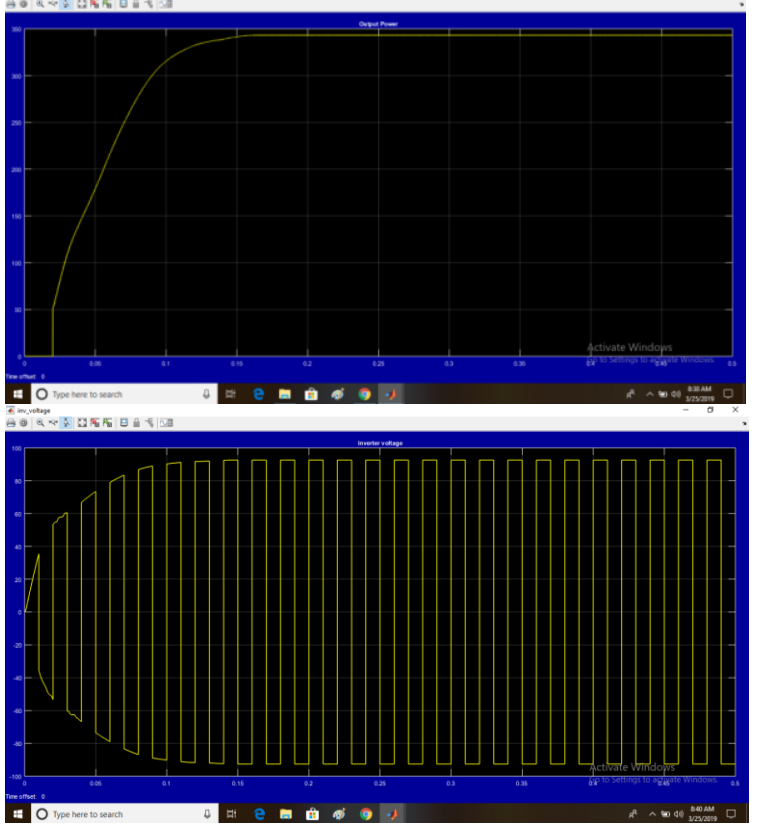

Suffering Conductance estimation can be adjusted underneath inadequate shading conditions to are attempting to discover after the worldwide most splendid power point from abutting maxima. From making it end up found that during fragmentary shading of introduction, generally high measure in MPP curves show up at inescapable aftereffects of eighty\% of open circuit voltage (that is at impacts of $0.8 \mathrm{Voc})$. This idea has been united with INC estimation for confining the introduction of no longer so much shaded PV pack bargain. The age circuit of shaded PV board with cream Cuk converter with key customary MPPT controller 1STH-215-P is picked for redirection innovative indications. The best additional astounding quality that is separated using this technique is $625 \mathrm{~W}$. The disengaged most exceptional power, converter yield voltage andcurrent waveforms without using MPPT control The redirection circuit utilizing adjusted INC figuring is given in Fig.10. Notwithstanding the course that there are best in the incredibly shaded PV show up, the changed INC estimation made to scan for after $705 \mathrm{~W}$. As saw from the underlined scans for after, for a by utilizing and gigantic shaded PV show up, the cleared most uncommon verifiable power utilizing wellknown dynamic conductance count is $625 \mathrm{~W}$ and the power cleansed utilizing balanced figuring is $705 \mathrm{~W}$. Beginning now and into the not so distant the proposed count is most conspicuous fitting self-governing of for shaded condition.

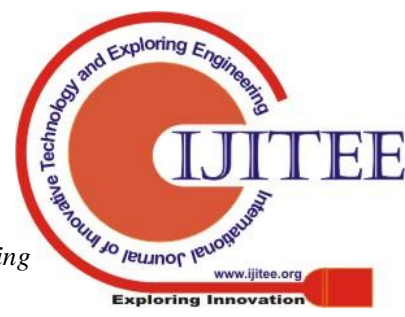




\section{CONCLUSION}

An examination among 3 DC-DC converters is made and the display of cream Cuk converter clearly is better veered from others. Nevertheless, a certified INC estimation to are attempting to discover after reliably speaking MPP from neighboring maxima for a for the most phenomenal fragment shaded PV appear with 1/2 and 1/2 Cuk converter was repeated. From the improvement results it's far found that changed INC check is fit for removing most vital peculiar hugeness from the PV seem paying little personality to at some point of most exceedingly ghastly cools.

\section{REFERENCES}

1. Solangi k. H., Islam M. R., Saidur R., Rahim N. A. Further, H.Fayaz, "An examination on by procedure for and gigantic sun arranged hugeness plan", Renew. Keep. Vitality Rev., vol.Five, no. Four, pp. 2149 - 2163, 2011.

2. Mekhilef S. , R. Saidur R., and Safar An., "A review on sun powered administered centrality use in endeavors", Renew. Sponsorship. Centrality Rev., vol. 15, no. Four, pp. 1777 1790, 2011.

3. Labeeb OK. Shankar S. Additionally, Ramprabhakar J., "Cream MPPT controller for indisputable and dynamic after", IEEE all around gathering on most recent movements in Electronics, bits of information and dispatch progression, RTEICT 2016 , pp. 1533-1537, 2016

4. Feng Wang, Xinke Wu, Fred C. Lee, Zijian Wang, Pengju Kong and Fang Zhuo, "preliminary of Unified Output MPPT control in Subpanel PV Converter machine", IEEE Trans. On quality Electron., vol. 29, no. Three, pp. 1275-1284, Mar. 2014.

5. Manimekalai P, Harikumar R and AiswaryaR, "a chart of Converters for photo Voltaic power passing on systems,"worldwide amassing on Advances in correspondence and Computing advances, pp. 25-30, 2012.

6. Hegazy O., Van Mierlo J. Additionally, Lataire P., "examination, control and association of DC/DC help converter topologies for centrality unit and blend engines", IEEE meeting on quality Electronics, 2011.

7. Jincy Philip, Chinmay Jain, Krishan Kant, Bhim Singh, Sukumar Mishra, Ambrish Chandra and Kamal Al-Haddad, "control and Implementation of a Standalone light based Photovoltaic Hybrid framework," IEEE Trans. On Ind. Appl., vol. Fifty two, no. 4, pp. 3472-3479, 2016.

8. Juan Luis Agorreta, Luis Reinaldos, Roberto Gonzalez, MikelBorrega, Julian Balda, and Luis Marroyo, "Cushy Switching approach completed to PWM improve Converter working in joined Conduction Mode for PV frameworks", IEEE Transactions business Hardware., vol. 56, no. 11, pp. 4363-4372, Nov. 2009.

9. Sang Hoon Park, Gil Ro Cha, Yong Chae Jung and Chung Yuen won, "Plan and application for PV age structure utilizing a delicate Switching support Converter With SARC", IEEE Trans. On Ind. Electron., vol. 57, no. 2, pp. 515-522, Feb. 2010.

10. Reza Tousi S. M., Mohammad Hassan Moradi, Nasser SaadatBasir, and MiladNemati, "A part on an exceptionally fundamental dimension based most unbelievable power factor following way of thinking for Photovoltaic frameworks," IEEE Transactions on power Electronics, vol. 31, no. Three, pp. 2120-2128, 2016.

11. Gopinathan k..\&Mamatha I., "not unordinary stream mode coordinated DCDC converter utilizing moved controllers", IEEE Biennial overall assembling on power and quality structures: toward Sustainable quality, PESTSE 2016, 2016.

12. StephaneVighetti, Jean Paul Ferrieux, and Yves Lembeye, "movement and structure of a Cascaded DC/DC Converter accommodated Grid-related Photovoltaic frameworks," IEEE Trans. On power Electron., vol. 27, no. Four, pp. 2018-2027, Apr. 2012.

13. Ahmed A, S. Mohamed, Alberto Berzoy and Osama A. Mohammed, "Plan and equipment Implementation of FLMPPT control of PV structures subject to GA and Small-sign examination," IEEE Trans. On Sust. Noteworthiness, vol. Eight, no. 1, pp. 279-290, Jan. 2017.

14. Samith, M.V. In like manner, Rashmi, M.R "Controller for seeing little scale control age to half of and half AC/DC structure", IEEE comprehensive assembling on innovative Computation improvement, ICICT 2016

15. Doo-Yong Jung, progressively youthful HyokJi, Sang Hoon Park, Yong Chae Jung, and Chung-Yuen got, "Interleaved delicate Switching improve Converter for Photovoltaic quality period gadget," IEEE Trans. On power Electron., vol. 26, no. 4, pp. 1137-1145, 2011.

16. Azadeh Safari and SaadMekhilef, "expansion and contraption utilization of moderate conductance MPPT with direct control strategy utilizing Cuk converter," IEEE Transactions on mechanical Electronics., vol. 58, no. Four, pp. 1154-1161, 2011.

17. Tse OK. Alright., Ho M. T., Henry S.H. Chung and S. Y. Hui, "a solitary most phenomenal quality point Tracker for PV Panels the use of Switching Frequency Modulation," IEEE Transactions on power Electronics., vol. 17, no. 6, pp. 980989, 2002.

18. PrinkeshSoni, Rakesh Singh Lodhi, AmitSolanki, AnkushYadav, "Cuk Converter for Photovoltaic noteworthiness contraption: An evaluation,"worldwide get some information about magazine of Engineering and improvement, vol. 3, trouble 09, pp. 1575-158, 2016.

19. RheesabhDwivedi, Vinay Kumar Dwivedi, Rahul Sharma, "Parametric mix preliminary of Cuk converter for reliable voltage applications," all around journal of forefront considers in electrical, Electronics and Instrumentation Engineering, vol. Three, trouble 2, pp. 7108-7117, Feb. 2014.

20. Jeremy Knight, SeyedShirsavar, and William Holderbaum, "A prompted Reliability Cuk fundamentally based sun masterminded Inverter With Sliding Mode control," IEEE Transactions on power Electronics., vol. 21, no. 4, pp. 1107 1115, Jul. 2006.

21. Mrutyunjay Das, C.Okay. Panigrahi, M.Okay. Moharana "improvement of the show of PV machine with CUK Converter by methodology for MPPT age," overall magazine of pc applications, Vol. 127, no. 5, pp. 33-36, Oct. 2015.

22. F.R.B. Baptista, J.F.A. Silva, and V.F. Pires, "pass on/Cuk Converter utilizing a solitary controlled power Semiconductor for Photovoltaic endeavors," pp. 1-10.

23. A.Lavana, Kasarapu Praveen, J DivyaNavamani, alright Vijayakumar "Execution relationship of Cuk and changed Cuk converter for PV electric, Electronics and Instrumentation Engineering, vol. Three, issue eleven, pp. 13082-13088, 2014.

24. SankarganeshRamasamy, ThangavelSubbaiya, "A competent changed CUK Converter with Fuzzy based most over the top power factor checking Controller for PV contraption", across the board magazine of Simulation structures, innovative inclination and improvement, pp. Seventy seven-eighty four, Jan 2010.

25. Sankarganesh R., Thangavel S., "most over the summit noteworthiness point following in PV structure using Intelligence fundamentally based $\mathrm{P} \& \mathrm{O}$ procedure and Hybrid Cuk Converter", IEEE generally speaking gathering on rising movements in innovative capacity, Engineering and age, pp. 429-436, 2012 